Jurnal Bimbingan Konseling
$10(1)(2021): 1-7$

\title{
The Relationship Between Self-Regulation, Parent-Adolescent Attachment and Self-Concept With Online Game Addiction
}

\author{
Lyanna Oktavia ${ }^{\bowtie}$, Sugiyo Sugiyo, Awalya Awalya \\ 1. SMAN 8 Semarang, Indonesia \\ 2. Universitas Negeri Semarang, Indonesia
}

\begin{abstract}
Article Info
Abstract

History Articles

The ease of internet access enables a lot of students to play online games.

Received:

5 January 2021

Accepted:

11 February2021

Published:

30 April 2021

However, if the online games are uncontrollably played, students will get addicted. This study aimed to determine the relationship between selfregulation, parent-adolescent attachment, and self-concept with online game addiction tendency by Public Senior High School students in Semarang City amounted to 391 people. Quota random sampling and self-regulation questionnaire adopted from Miller \& Brown (1991), attachment scale adopted

Keywords:

Self-regulation, parentadolescent attachment, self-concept, online game addiction from Gullone and Robinson (2005), self-concept scale (Tennessee Self-Concept Scale) from Burn (1993), and online game addiction from Lemmens (2009) were used to sample the students. Findings showed that the online game addiction tendency by the students of Public Senior High School in Semarang City was low. Further, the researchers found that self-regulation, attachment, and self-concept had negative and significant relationships with online game addiction. To follow-up these findings, prevention needs to be addressed to online game addiction by strengthening self-regulation, positive self-concept and building parents and adolescents interactions.
\end{abstract}

\footnotetext{
$凶$ Correspondence address:

Gedung A Kampus Pascasarjana UNNES, Jl. Kelud Utara III,

Semarang, 50237

E-mail: 1yannaok78@gmail.com
} 


\section{INTRODUCTION}

Problematic internet use has been an issue for some adolescents. It is complex and multifaceted (Wang, 2001). In daily life, the problem can be found in the way students play game and access social media while learning process is in progress (Oktaviani, 2011). As stated by Shen and Williams (2011) online game is a form of popular entertainment which may affect the quality of its player. More notably, it will bring negative effects for students if they do not effectively access and play that game. Yovanka in Eka, et al. (2020) state that students who are addicted to online game tend to have lower motivation than those who play it for spending leisure time. Consequently, those who are addicted will get difficulties in managing daily activities (Pujiastuti, 2015). Online game addiction also has negative impacts on adolescents' personality, low academic scores, unhealthy sleep time, irregular eating patterns and healthiness (Kusumah, 2011).

Senior High School students' online game excessive behavior is increasing day by day and makes the number of addicted players increase. One thing which causes this phenomenon is the lack of self-regulation (Effendi, 2017), low self-control (Mehroof \& Griffith, 2010; Wan and Choiu, 2007; Teng, Li and Liu, 2014) and the existence of conflicts between adolescents and parents resulting in disruption of parents-adolescents attachment (Yen et al, 2007: 325; Agarwal, Agarwal \& Mallick, 2014; Prastiwi Yunita Dewi, 2009; Liu and Kuo, 2007). In fact, the various tendencies of online game addiction can be reduced if adolescents have good self-regulation, selfconcept, and adolescent-parent attachment. Through good self-regulation, adolescents can retain cognition, behavior and affection to systematically orient towards the achievement of their goals. Similarly, adolescent-parent attachment through good communication can prevent compulsive internet and online game use (Van de Eijnden, et al, 2010: 87). Acceptance from other people and friends can also indirectly develop adolescents' positive self-concept to reduce online game addiction. It is because one of factors that influences self-concept is peers (Hurlock, 2002).

Self-regulation is a variable that contributes to aggression modulation and positive psychological characteristics development which in turn can reduce negative effects from the internet. This variable is significant for helping an individual controlling his surroundings and emotional impulses that can interfere his development (Cervone \& Pervin, 2010). Self-ability needs to be owned by an individual to be free from online game addiction. Based on Seay A. F. study (2007) online game addiction can be changed and prevented using good self-regulation. Without regulation, time and frequency of online gaming will affect the players and lead to addiction (Carey and Neal, 2004).

Adolescents will have difficulties in managing time spent playing online games without effective supervision from family (Yen, et al, 2007). Conflicts between adolescents and parents and low satisfaction from family functions are related to internet addiction, for parental roles are needed to prevent adolescents from compulsively playing online games. Another cause is parenting patterns. Adolescents with uncontrolled parenting will release their inconveniences emotionally and psychologically by playing online games. This matter is strongly connected to online game addiction by adolescents (Braumrind, 1991).

One's self-concept can be formed by a tendency of playing online games and result in the withdrawal from a process. This desire leads a person to neglect daily life problems. Agarwal and Mallick (2014) in their study conclude the constructs of self-concept (health and sex suitability, ability, self-confidence, selfacceptance, worthiness, belief, guilt, friendliness, emotion in the present, past and future) are negatively correlated to online game addiction. Therefore, self-concept is possibly assumed as the source of online game addiction by an individual.

Studies of online game addiction have been done by many researches in some countries 
in Europe such as UK (Mehroof \& Griffith, 2010), the Netherlands (Van de Eijden et al, 2010: 87) and China (Teng, Li and Liu, 2014). Some are even done by Indonesian. Unfortunately, the analyses have been mostly focused on the effects of online game addiction and factors influencing children to get addicted by online game (Anandari, 2013). Accordingly, the current study attempted to investigate this phenomenon from the perspectives of selfregulation, adolescent-parent attachment, and self-concept on online game addiction. This was motivated by the need of predicting selfregulation, adolescent-parent attachment and self-concept of students who are addicted to online games so that guidance and counseling teachers would have a basis for preventing students from online game addiction. Besides, the findings of this study can be a basis for the future studies. Given these concerns, this study aimed to analyze the relationship between selfregulation, adolescent-parent attachment, and self-concept on online game addiction by Senior High School students.

\section{METHODS}

In conducting this study, the researchers took respondents from eight Public Senior High School in Semarang City using quota random sampling and sloving formula at $5 \%$ degree of error. Of these methods, there obtained 391 students as the respondents who were later assigned to fill in four psychological scales.

Students' online game addiction data were measured using Lemmens scale (2009) covering seven aspects, namely salience, tolerance, mood modification, withdrawal, relapse, conflict and problems. This scale has 21 favorable statement items with good results of validity and reliability test, namely $(0.38-0.80)$ for the validity range and $(0.90)$ for the reliability.

Self-regulation in this study was measured using SRQ (Self-Regulation Questionnaire) developed by Miller \& Brown (199). It consists of 63 statement items including 36 favorable items and 27 unfavorable items distributed randomly. These items were designed based on seven components of self-regulation, namely: (1) Receiving; (2) Evaluating (evaluating information and comparing it with norms); (3) Triggering (pushing to change); (4) Searching (looking for options); (5) Formulating (formulating plans); (6) Implementing (implementing the plan); and (7) Assessing (assessing the effectiveness of the plan). One example of the item is "I always monitor track of my progress toward my goals." Regarding validity and reliability tests, this instrument has a good result that are $(0.39-0.70)$ for validity range and (0.91) for reliability.

Adolescent-parent attachment was measured using a scale developed by Gullone and Robinson (2005). 25 statement items are available in this scale, including 15 favorable items and 10 unfavorable items distributed randomly. These items explain three indicators, namely trust, communication, and alienation. One of its statement is "I believe in my parents". Based on validity and reliability tests, this instrument has validity range of (0.37-0.67) and reliability of (0.87) indicating that the instrument is good.

To measure self-concept, the researchers used Tennessee Self-Concept Scale created by Burn (1993). It has 100 statement items containing 10 items indicating self-criticism score and 90 items indicating self-esteem. Of 100 items, this instrument divides them into 55 favorable items and 45 unfavorable items randomly based on two dimensions, namely internal dimension consisting of three parts (Identity self, judging self and behavioral self) and external dimension covering five parts (physical self, moral-ethical self, personal self, family self and social self). One example of an item on this scale is "I don't think my family has any faith in me". The results of the validity and reliability tests state that this scale has a good level of validity and reliability. Its validity ranges from (0.37-0.67) and reliability (0.95). All scales in this study were in the form of a Likert scale consisting of 5 scaling scores $(1=$ Strongly Disagree, $5=$ Strongly Agree). 
In analysis process, the researchers used Microsoft Excel and SPSS software. The data of information source profile and variables were calculated and presented in form of table. For the variable data, the researchers made a classification ranging from very low, low, high, and very high based on respondents' achievement. Once the respondents were given scores according to the terms and conditions stated in the data collection procedures, their data were then analyzed using multiple linear regression analysis. Before that, linearity and data normality tests were done through Kolmogorov smirnov test and heteroscedasticity test.

\section{RESULTS AND DISCUSSION}

The results of descriptive statistical data measured using Self-Regulation Questionnaire obtained the value of $(M=156.8 ; S D=25.1)$. Next, the predictor of attachment gained the value of $(\mathrm{M}=71.2$; $\mathrm{SD}=11.2)$, while selfconcept predictor measured using Tennessee Self-Concept Scale got a value of $(\mathrm{M}=216.4$; $\mathrm{SD}=25.8)$. The last, variable of online game addiction tendency gained the value of $(\mathrm{M}=$ 42.4; $\mathrm{SD}=10.2)$. Detailed results can be seen as follows:

Table 1. Categories of the Level of Self-Regulation, Attachment, Self-Concept and Online Game Behavior Tendencies

\begin{tabular}{llllll}
\hline Criteria & $\begin{array}{l}\text { Self-Regulation } \\
(\%)\end{array}$ & $\begin{array}{l}\text { Adolescent-Parent } \\
\text { Attachment } \\
(\%)\end{array}$ & $\begin{array}{l}\text { Self- } \\
\text { Concept } \\
(\%)\end{array}$ & $\begin{array}{l}\text { Online } \\
\text { Addiction } \\
(\%)\end{array}$ & Game \\
\hline Very High & 5.1 & 6.1 & 1.8 & 0.3 \\
High & 71.6 & 66.8 & 56.8 & 7.4 & \\
Low & 17.6 & 22.3 & 38.9 & 60.4 & \\
Very Low & 5.6 & 4.1 & 2.6 & 32.0 & \\
\hline Mean & 156.8 & 71.2 & 216.4 & 42.4 & \\
\hline SD & 25.1 & 11.2 & 25.8 & 10.2 & \\
\hline
\end{tabular}

Table 1 shows online game addiction was in the low category (60.4\%) and the level of student self-regulation was in the high category (71.6\%). In addition, the description of the attachment of parents and adolescent was in the high category $(66.8 \%)$ and self-concept was in the high category $(56.8 \%)$.

Table 2. The Results of Multiple Linear Regression Analysis on Online Game Addiction

\begin{tabular}{lcllllll}
\hline Predictors & $\beta$ & $\mathrm{t}$ & $\mathrm{p}$ & $\mathrm{R}$ & $\mathrm{R} 2$ & $\mathrm{~F}$ & $\mathrm{p}$ \\
\hline Criterium: Online Game Addiction & & & 0.51 & 0.26 & 47.58 & $<0.01$ \\
Self-Regulation & -0.31 & -6.44 & $<0.01$ & & & & \\
Kelekatan | Attachment & -0.42 & -9.23 & $<0.01$ & & & & \\
Self-Concept & -0.39 & -8.34 & $<0.01$ & & & & \\
\hline
\end{tabular}

By referring to table 2 , it is understandable that self-regulation and online game addiction had a significant relationship ( $\beta=-0.31 ; \mathrm{t}$ (1.389) $=-6.44 ; \mathrm{p}<0.01)$. Thus, self-regulation was $\mathrm{a}$ significant predictor of students' online game addiction. Meanwhile, the value of $\beta=(-0.31)$ meant that self-regulation had a negative relationship with the online game addiction by (31.1\%). Moreover, there was a significant relationship between attachment and online game addiction $(\beta=-0.42 ; \mathrm{t}(1.389)=(-9.23) ; \mathrm{p}$ $<0.01)$. It indicated that attachment performed 
as a significant predictor of students' online game addiction. Since the value of $\beta$ got (-0.42), it meant that attachment had a negative relationship with online game addiction (42.4\%).

Furthermore, the results of analysis in table 2 also proved that there was a significant relationship between self-concept and game online addiction $(\beta=-0.39 ; \mathrm{t}(1.389)=-8.34 ; \mathrm{p}$ $<0.01)$ explaining that self-concept was a significant predictor of students' online game addiction. The value $\beta=(-0.39)$ conveyed that self-concept had a negative relationship with online game addiction by (39.0\%) supported by a study by Agarwal and Mallick (2014) which revealed that online game addiction is getting higher in negative self-concept. Again, table 2 informs a significant regression equation ( $F$ $(3.38)=47.58<0.01)$ with $\mathrm{R}$ value of $(0.51)$. Hence, self-regulation, attachment and selfconcept apparently became the significant predictor of online game addiction. In details, self-regulation, adolescent-parent attachment, and self-concept jointly and simultaneously explained online game addiction variable (26.9\%)

The findings of this study are in line with Pujiastuti's study (2015) which argues that there is a negative relationship between selfregulation and online game addiction. The addiction depends on oneself, not one's surroundings. Students' control of online game will be greatly influenced by self-regulation. Baron and Byrne (2005) state that secure attachment is a bond made between parents and children to form an individual who has great self-esteem, self-confidence, interpersonal attitudes, and positive thoughts about himself and others. It is one of main factors contributing to social skills. In other words, the increase in parental attachment will provide meaningful contribution to social skills. According to social theorist, Erik Erikson, this effort is surely helpful for children psychosocial development especially in the period of trust versus mistrust. In this period, belief will be instilled within children based on their attached figures. This belief will exist when children get enough comfort, security and affection from parents. Conversely, if the treatment received by children is far from a sense of security, lack of affection from their attached figures mistrust will develop within them. Children will easily be suspicious of other people, grow into a person who has low selfconfidence and get difficulties in the acceptance by their social environment.

In accordance with the findings, online game addiction experienced by students was caused by low self-regulation, negative selfconcept, and low attachment. This is supported by Lei and $\mathrm{Wu}$ (2007) who describe attachment as a pathological factor that emerges online game addiction. Correspondingly, Ban Den Eijnden, et al (2010) mention online game addiction can be compulsively prevented by parents' roles.

An implication that can be done in the field of guidance and counseling is that guidance and counseling needs to pay attention to the health of individual development. According to Dollarhide (2011) development guidance and counseling would truly play a significant role in dealing and preparing today's adolescents to have good quality, especially the roles of guidance and counseling in coping with students who have online game addiction in relation to the improvement of self-regulation, self-concept, and parent-student attachment so that the students can perform their personal and social functions well.

\section{CONCLUSION}

On the report of the findings, it can be concluded that self-regulation has a negative and significant relationship with online game addiction, parent-adolescent attachment variable has a negative and significant relationship with online game addiction, self-concept variable has a negative and significant relationship with online game addiction, and those variables jointly have negative and significant relationships with online game addiction by students in SMA Negeri in Semarang City both partially and fully.

School counselors are suggested to provide effective efforts to strengthen students' 
self-regulation, build active interactions between parents and students, and encourage students to have positive self-concept. All these things are focused on the prevention of online game addiction by students.

\section{REFERENCES}

Agarwwal, A,\& Mallick, P. (2014). A Study of Relationship Between Internet Addiction and Self-concepts of Adolecents. Indian Journal of Health and Wellbeing, 5(2), 219-221.

Anandari, D.R. (2013). Orangtua dengan Pola Asuh Permisif dan Resiko Anak Kecanduan Game Online. Surabaya: Universitas Airlangga.

Baron, R.A., \& Byrne, D. (2005). Psikologi sosial. 10th ed. Jakarta: Erlangga.

Braumrind. (1991). The Influence of Parenting Style on Adolescent Competence And Subtance Use. Journal of Adolescent 11 (1).

Burns, R.B. (1993). Konsep Diri (Teori, Pengukuran, Perkembangan dan Prilaku). Jakarta : Arcan.

Carey, K. B., D. J. Neal, dkk. (2004). A psychometric analysis of the selfregulation questionnaire. Addictive Behaviors.

Cervone, Daniel \& Lawrence, A. Pervin. (2012). Kepribadian : teori dan penelitian. Jakarta: Salemba Empat.

Dollarhide et al (2011). Counseling Made Transparent: Pedagogy For A Counseling Theories Course. Counselor Education and Supervision. Volume 46, Issue 4. June 2007 Pages 242253.https://onlinelibrary.wiley.com/doi/ abs/10.1002/j.15566978.2007

Eka,S.W.,Firman. (2020). Efektifitas Layanan Bimbingan Kelompok DalamPenigkatan Self Regulated Learning Siswa Pengguna Game Online. Jurnal Neo Konseling, DOI: $10.24036 / 00286$ kons 2020

Gullone E. \& Robinson K. (2005.) The Inventory of Parent and Peer Attachment - Revised (IPPA-R) for Childer : A
Psychometric Investigation. Clinical Psychology and Psychotherapy (12). 6779.

Hurlock, E.B. (2002). Psikologi Perkembangan: Suatu Pendekatan Sepanjang Rentang Kehidupan. Edisi Kelima. Jakarta: Erlangga.

Kusumah, R.T. (2011). Konsep Diri Pecandu Game Online (Studi Deskriptif Tentang Konsep Diri Pecandu Game Online di Kota Bandung). Undergraduate Theses Unpublised, Bandung Universitas Komputer Indonesia http://alumni.unikom.ac.id

Lemmens JS, Valkenburg PM, Peter J. (2009). Development and Validition of A Game Addiction Scale for Adolescent. Media Psychology 12: 77-95.

Lei, Li \& Wu, Yana. (2007). Adolescents' Paternal Attachment and Internet Use. Cyberpsychology \& behavior : the impact of the Internet, multimedia and virtual reality on behavior and society. 10. 633-9. 10.1089/cpb.2007.9976.

Liu, C. Y. dan Kuo, F. Y. (2007). A Study Internet Addiction Through The Lens Of The Interpersonal Theory. CyberPsychology \& Behavior, 10, (6), 799-804.

Mehroof, M., \& Griffith, M, D. (2010). Online gaming addiction: The role of sensation seeking, Self control, Neuroticism, Aggression, State anxiety, And trait anxiety. Journal Cyberpsychology, Behavior, and Social Networking.13, (3).

Miller W.R \& Brown J. M. (2005). Self Regulation as a Conceptual Basis for The Prevention And Treatment of Addictive Behaviours. In N. Heather, W. R Miller \& J. Greeley (Eds). Self Control And The Addictive Behaviours (pp. 3-79). Sydney: Maxwell Macmillan Publishing Australia.

Oktaviani, E. (2011). Pengaruh Penggunaan Smartphone Pada Remaja. Jurnal Ilmiah Psikologi. (5), No. 1, 30-41

Pujiastuti, D. F. (2015). Hubungan antara regulasi diri dengan kecendrungan adiksi game online pada remaja awal. 
http://repository.uksw.edu/bitstream/12 3456789/8628/2/T1_802008040_Ful1\%2 0text. Pdf

Effendi, R.M.S.(2017). Regulasi Diri dalam Belajar (Self-Regulated Learning) Pada Remaja yang Kecanduan Game Online. Psikoborneo; Jurnal Ilmiah psikologi. Vol 5, No 2 : , Issue 2, June DOI: 10.30872/psikoborneo

Seay, A. F., Kraut, R.E. (2007). Project Massive: Self-Regulation and Problematic Use of Online Gaming. Proceedings of the CHI 2007. San Jose, CA, USA.

Shen, C., \& Williams, D. (2011). Unpacking time online: Connecting internet and massively multiplayer online game use with psychosocial well-being. Communication Research, 38(1), 123149. Doi.10.1177/0093650210377196

Teng, Z., Yujie, L., \& Yanling, L. (2014). Online gaming, internet addiction, And aggression of Chinese male sudents: The mediating role of low self-control. International Journal of Psychological Studies.6, (2).

Van den Eijnden, R.J.J.M., Spijkerman, R., Vermulst, A.A., van Rooij, T.J., \& Engels, R.C.M.E. (2010). Compulsive Internet Use Among Adolescents: Bidirectional Parent-Child Relationships. Jounal Abnormal Child Psychology, 38, 77-89.

Wang, W. (2001). Internet dependency and psychososial maturity among college students. International Journal of Human-Computer Studies. 55. 919-938.

Yen, J. Y., Yen, C. F., Chen, C. C., Chen, S. H., \& Ko, C. H. (2007) Family Factors of Internet Addiction and Substance Use Experience in Taiwanese Adolescents. CyberPsychology 